\title{
Development of Daphnia magna under exposure to the xenobiotic octylphenol
}

\author{
Sụ phát triển của Daphnia magna trong phơi nhiễm với hợp chất tổng hợp \\ octylphenol
}

Research article

\begin{abstract}
Dao, Thanh Son ${ }^{*}$; Vo, Thi My Chi ${ }^{2}$, Do, Hong Lan Chi ${ }^{2,3}$; Nguyen, Phuoc Dan ${ }^{1}$
${ }^{1}$ Hochiminh City University of Technology, 268 Ly Thuong Kiet Street, District 10, Hochiminh City, Vietnam; ${ }^{2}$ Institute for Environment and Resources, 142 To Hien Thanh Street, Distric 10, Hochiminh City, Vietnam; ${ }^{3}$ Vietnam National University - Hochiminh City, Linh Trung Ward, Thu Duc District, Hochiminh City, Vietnam.
\end{abstract}

\begin{abstract}
Xenobiotics are of human and environmental concerns due to their potential toxicity. Octylphenol is one of the very common and daily used xenobiotics in door and out door activities of human beings. Toxicity of octylphenol to aquatic organisms, especially to zooplankton (e.g. Daphnia magna) was investigated but not fully understood. In this study we evaluated the chronic effects of octylphenol at the concentrations of 5, 50 and $500 \mu \mathrm{g} \mathrm{L}^{-1}$ on Daphnia magna over a period of 14 days. The results showed that low concentration of octylphenol $\left(5 \mu \mathrm{g} \mathrm{L}^{-1}\right)$ stimulated the maturation while high concentrations of the chemical $\left(50\right.$ and $\left.500 \mu \mathrm{g} \mathrm{L}^{-1}\right)$ caused a significant mortality to the Daphnia. Besides, all the tested concentrations of octylphenol had serious impacts on fecundity and growth of the animals. Investigations on the presence, distribution, fate and toxicity of xonobiotics including octylphenol in the developing country environment are suggested for human, environmental and ecological health protection.
\end{abstract}

\begin{abstract}
Nhũng hợp chất tổng hợp đang là mối quan ngại cho con người và môi truờng vì khả năng gây độc của chúng. Octylphenol là một trong nhũng hơp chất tổng hợp được sủ dụng phổ biến và thuờng xuyên trong nhũng hoạt động của con nguời trong nhà và ngoài trời. Độc tính của octylphenol đối với thủy sinh vật, đặc biệt đối với động vật phù du (vd. Daphnia magna) mặc dù đã được nghiên cứu nhung vẫn chura được hiểu biết đầy đủ. Trong nghiên cưu này, chúng tôi đánh giá ảnh hwởng mãn tính của octylphenol ở các nồng độ 5, 50 và $500 \mu g$ /lít lên Daphnia magna trong thời gian 14 ngày. Kết quả cho thấy ở nồng độ octylphenol thấp (5 $\mu \mathrm{g} /$ lit) kích thich sư thành thuc của sinh vật trong khi ở nồng độ cao hơn (50 và $500 \mu \mathrm{g} / \mathrm{lit}$ ) gây chết đáng kể Daphnia. Bên cạnh đó, tất cả các nồng độ ocytlphenol dùng trong thí nghiệm gây ảnh hường nghiêm trọng lên sức sinh sản và sinh trương của sinh vật. Nghiên cưu về sụ hiện diện, phân bố, phát tán và độc tính của những chất tổng hợ bao gồm octylphenol ở các nước đang phát triển nên được tiến hành vì muc tiêu bảo vệ súc khỏe con người, môi trường và hệ sinh thái.
\end{abstract}

Keywords: octylphenol, Daphnia magna, chronic effects, reproduction, growth

\section{Introduction}

Recently, the focus on chemical pollution has been largely directed toward the well-known "priority" pollutants, especially those displaying persistence in the environment. This is likely to be only one piece of a larger puzzle (Daughton and Ternes, 1999). Other surface water contaminants include a variety of metals, carcinogenic organic compounds, xenobiotics, pharmaceutical, veterinary, personal care products, and food supplements among others (Weyer and Riley, 2001; Kolpin et al., 2002). Xe- nobiotics can act as endocrine disruptors without affecting hormone binding by modulating endogenous hormone levels.

The main sources of endocrine-disrupting compounds in the rivers and lakes of Europe and North America are sewage effluent and agricultural chemicals from runoff. In less developed countries uncontrolled domestic and industrial discharge to waterways contributes to EDCs (Barnhoorn et al., 2004). Many anthropogenic chemicals, as well as naturally occurring estrogens and plant secondary 
metabolites, experimentally have been found to have endocrine-disrupting properties (Naz, 2005). Octylphenol, an alkylphenol, is one of the endorine disrupting compounds widely used in as industrial surfactants, bases for household products, fungicides, textile and leather auxiliaries, veterinary medicine formulations, and thousands of tonnes of octylphenol have been annually used in the world (Brooke et al., 2005).

Researchers were first alerted to aquatic contamination by endocrine-disrupting compounds through observation of a variety of reproductive changes in different aquatic organisms (Folmar et al., 2001; Gagne et al., 2002). Octylphenol could be accumulated in freshwater and marine fish and mussel (Brooke et al., 2005). This chemical caused acute and chronic effects on embryos, larvae and offspring, juvenile aquatic animals, mostly on fish (e.g. fathead minnow, rainbow trout, carp) and invertebrates (freshwater shrimp, nematode worm, mysid shrimp, water flea). Few investigations showed adverse effects of octylphenol on Daphnia magna in terms of survival and body length (Brooke et al., 2005). However, other life history traits of D. magna, e.g. maturation, dry mass, fecundity, during a long-term exposure to octylphenol are not known, to our best knowledge. Therefore, this study aimed to evaluate the chronic effects of octylphenol at the concentrations of 5-500 $\mu \mathrm{g} \mathrm{L}^{-1}$ on life history traits of $D$. magna over a period of 14 days.

\section{Materials and methods}

\subsection{Materials}

The 4-n-Octylphelol (hereafter we call it octylphenol) was obtained from Merck (Dr. Ehrenstorfer $\mathrm{GmbH}$ ). The chemical was dissolved in $\mathrm{MeOH}$ (Merck) at the concentration of $1 \mathrm{mg} \mathrm{mL}^{-1}$. The stock solution was kept at $-70^{\circ} \mathrm{C}$ prior to the experiment. The purification of the commercial chemical is $99.5 \%$.

\subsection{Experimental organisms and experiment set up}

The test organism was Daphnia magna, obtained from MicroBioTest Inc. (Belgium) and has been maintained in the laboratory of the Institute for Environment and Resources for many generations. The Daphnia medium consisted of $\mathrm{CaCl}_{2}, \mathrm{KCl}, \mathrm{NaHCO}_{3}$ and $\mathrm{MgSO}_{2}$. Daphnia were fed with alga Scenedesmus sp. three times a week. The alga was cultivated in Z8 medium (Kotai, 1972) with continuous aeration. Both culturing of Scenedesmus and Daphnia and the exposures were conducted at $20 \pm 1^{\circ} \mathrm{C}$ and a photoperiod of $14 \mathrm{~h}$ light: $10 \mathrm{~h}$ dark at a light intensity of around 1000 Lux.

Prior to the experiments, fifteen female D. magna were incubated in a $500 \mathrm{~mL}$ beaker and fed with Scenedesmus sp. for 2-3 weeks. Offspring from the second to fifth clutch of these D. magna were used for experiments. Daphnia was exposed to octylphenol at the concentrations of $0,5,50$ and $500 \mu \mathrm{g} \mathrm{L}^{-1}$. In each treatment, thirty neo- nates less than $24 \mathrm{~h}$ old were randomly selected for each chronic exposure (Adema, 1978) and ten organisms were incubated in $200 \mathrm{~mL}$ plastic beakers containing $100 \mathrm{~mL}$ of medium. Three replicates were prepared for each treatment.

The animals were fed with Scenedesmus sp. at the concentration of $2 \mathrm{mg} \mathrm{C} \mathrm{L}^{-1}$ per day. The medium were totally renewed 3 times every week. During incubations, animals were observed daily for their survival, maturation and reproduction. Death of the animal was defined as the stop of heartbeat confirmed by microscopic observation (Olympus BX51, coupled with a digital camera). Maturation of Daphnia was defined as time point of first egg occurrence in the brood chamber (could be seen with naked eyes). Fecundity of the animals was defined as the accumulative neonates from an exposure (Dao et al., 2010). The experiments lasted for 2 weeks. By the end of the tests, the alive Daphnia was dried at $50^{\circ} \mathrm{C}$ for 4 hours then weighed for dry mass determination.

\subsection{Data analysis}

Shapiro Wilk test (Sigma Plot, version 12.0) was applied to determine the significant difference of Daphnia's maturation and dried mass from control and octylphenol exposures.

\section{Results and discussion}

\subsection{Survival of Daphnia magna}

During two weeks of incubation all D. magna in the control were alive. The low concentration of octylphenol $\left(5 \mu \mathrm{g} \mathrm{L}^{-1}\right)$ slightly impacted on the survival of Daphnia. However, the higher concentrations of octylphenol, 50 and $500 \mu \mathrm{g} \mathrm{L}^{-1}$, caused a significant reduction of the organisms' survivorship to $73 \%$ and $53 \%$, respectively (Fig. 1). A previous investigation showed that all D. magna died after 9 day exposure to the 4-tert-octylphenol at the concentration of $510 \mu \mathrm{g} \mathrm{L}^{-1}$ (Brooke et al., 2005), similar to the highest concentration in our study, $500 \mu \mathrm{g} \mathrm{L}^{-1}$. The higher survival percentage in the current study could explained as (1) the chemical used in our study (4-noctylphenol) may be less to toxic to Daphnia than the chemical used in the previous study (4-tert-octylphenol) and (2) different clones of Daphnia could have different tolerance to the same toxin concentration (Hietala et al., 1997). On the other hand, the effects of octylphenol on survival of Daphnia in this study is in line with a recent publication of Vo et al (2014) in which the animals were exposed to atrazine. 


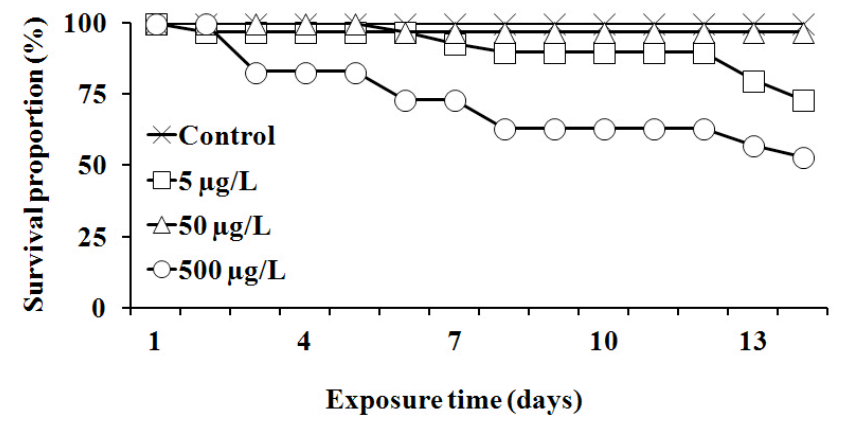

Figure 1. Survival of Daphnia magna $(n=30$ at the start) during 2 weeks of exposure to $0,5,50$ and 500 $\mu \mathrm{g} / \mathrm{L}$ of octylphenol

\subsection{Maturation of Daphnia magna}

Octylphenol has been linked with estrogenic effects in fish (Jobling et al., 1996). Octylphenol at low concentration, $5 \mu \mathrm{g} \mathrm{L}^{-1}$, made the Daphnia reach their maturity age earlier compared to the control. However, at higher octylphenol concentrations, 50 and $500 \mu \mathrm{g} \mathrm{L}^{-1}$, the exposed animals had a similar age of maturation (Fig. 2). Maybe the maturation of the organisms was stimulated at low chemical concentration but inhibited at higher ones which needs further investigation. To our best knowledge, this is the first information on the maturation of D. magna exposed to octylphenol.

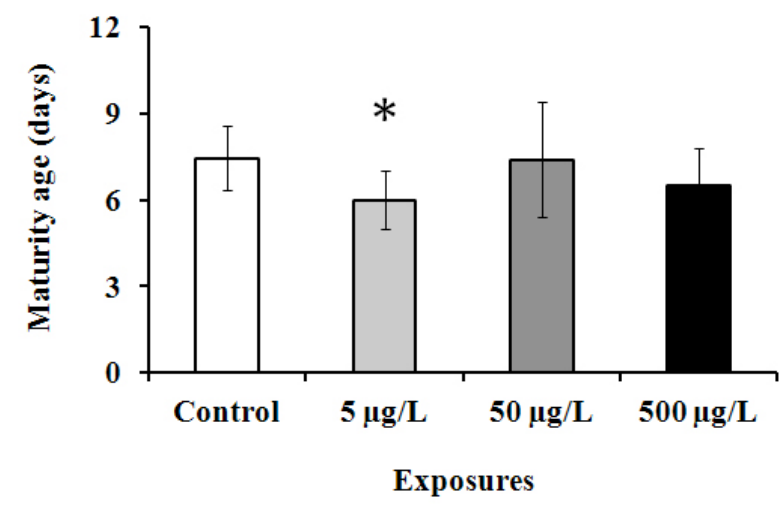

Figure 2. Maturation of Daphnia magna during 2 weeks of exposure to $0,5,50$ and $500 \mu \mathrm{g} / \mathrm{L}$ of octylphenol (*, p $<0.05$, Shapiro Wilk test)

\subsection{Reproduction of Daphnia magna}

Out of the 2 week incubation, there were 427 off spring from control experiment. However, the total accumulative neonates in the octylphenol treatments were from 11-55 (Fig. 3). Zhang et al. (2003) indicated that 4-nonylphenol at the concentration from $50-1000 \mu \mathrm{g} \mathrm{L}^{-1}$ arrested the Daphnia' egg development and caused malformation of Daphnia neonates. Because nonylphenol and octylphenol are both endocrine disrupting compounds and may share similar effects on animals, therefore, the strong influence of octylphenol on Daphnia' embryo development is the root of the severe effect of the chemical on the reproduction of Daphnia.

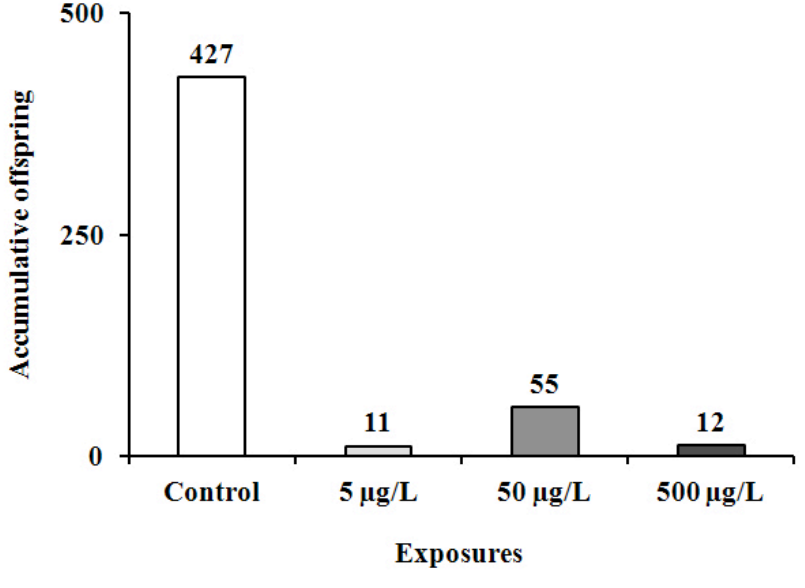

Figure 3. Accumulative offspring produced by mother Daphnia magna from control and octylphenol exposures

\subsection{Growth of Daphnia magna}

The average dry mass of one mother D. magna in the control was around $0.28 \mathrm{mg}$. In the exposures to 5,50 , $500 \mu \mathrm{g}$ octylphenol $\mathrm{L}^{-1}$, the dry mass of one animal was around $0.17,0.20,0.09 \mathrm{mg}$, respectively (Fig. 4). It was reported that octylphenol caused significant decrease of Daphnia's body length when they exposed to 120-230 $\mu \mathrm{g}$ octylphenol $\mathrm{L}^{-1}$, but the effect was not observed when the octylphenol concentration was $62 \mu \mathrm{g} \mathrm{L} \mathrm{L}^{-1}$ Brooke et al., 2005). Our study proved that the strong impact of the chemical on the growth of Daphnia was already observed at the very low concentration of octylphenol, $5 \mu \mathrm{g} \mathrm{L}^{-1}$.

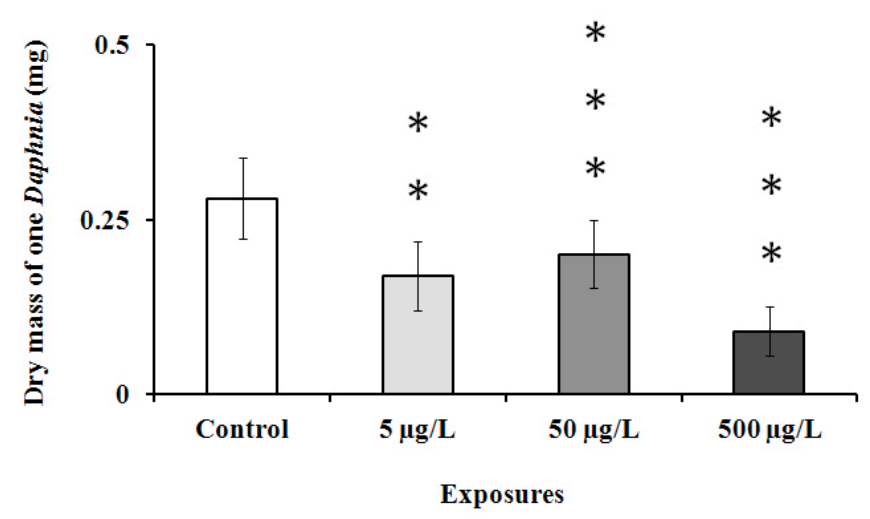

Figure 4. Dry mass of Daphnia magna after 2 weeks of exposure to $0,5,50$ and $500 \mu \mathrm{g} / \mathrm{L}$ of octylphenol (**, p $<0.01 ; * * *, \mathbf{p}<0.001$; Shapiro Wilk test)

\section{Conclusions}

The results of our investigation showed that the commonly and widely used chemical octylphenol had serious effects on the life history traits of D. magna including survival, maturation, growth and reproduction. To our knowledge, this is the first report on the chronic and negative effects of octylphenol on maturation and dry mass of D. magna. Therefore, more attention should be paid to the presence, distribution, fate in nature and impacts of octylphenol in particular and endocrine disrupting com- 
pounds in general on aquatic organisms. Additionally, investigations on the bio-accumulation and biotransformation of xenobiotics in animals are suggested to get more understanding on the toxicity of the toxins on the aquatic organisms and ecosystem.

Acknowledgement: This study was funded by the Vietnam National University - Hochiminh City under the granted project number B2014-48-01.

\section{References}

[1] Adema, D.M.M., 1978. Daphnia magna as a test animal in acute and chronic toxicity tests. Hydrobiologia 59, 125-134.

[2] Barnhoom, I.E.J., Bornman, M.S., Pieterssse, G.M., van Vuren, J.H.J., 2004. Histological evidence of intersex in feral sharptooth catfish (Clarias gariepinus) from an estrogen-polluted water source in Gauteng, South Africa. Environ. Toxicol. 19, 603-608.

[3] Brooke, D., Johnson, I., Mitchell, R., Watts, C., 2005. Environmental risk evaluation report: 4-tertoctylphenol. Environmental Agency, Bristol, 218pp.

[4] Dao, T.S., Do-Hong, L.C., Wiegand, C., 2010. Chronic effects of cyanobacterial toxins on Daphnia magna and their offspring. Toxicon 55, 1244-1254.

[5] Daughton, C.G., Ternes, T.A., 1999. Pharmaceuticals and personal care products in the environment: agents of subtle change? Environ Health Perspect 107, 907-938.

[6] Folmar, L., Denslow, N., Kroll, K., Orlando, E., Enblom, J., Marcino, J., Metcalfe, C., Guillette, L.J., 2001. Altered serum sex steroids and vitellogenin induction in walleye (Stizostedion vitreum) collected near a metropolitan sewage treatment plant. Arch. Environ. Contam. Toxicol. 40, 392-398.

[7] Gagne, F., Blaise, C., Aoyama, I., Luo, R., Gagnon, C., Couillard, Y., Campbell, P., Salazar, M., 2002.
Biomarker study of a municipal effluent dispersion plume in two species of freshwater mussels. Environ. Toxicol. 17,149-159.

[8] Hietala, J., Laurén-Määttä, C., Walls, M., 1997. Sensitivity of Daphnia to toxic cyanobacteria: effects of genotype and temperature. Freshwater Biol. 37, 299-306.

[9] Jobling, S., Sheahan, D., Osborne, J.A., Matthiessen, P., Sumpter, J.P., 1996. Inhibition of testicular growth in rainbow trout (Oncorhynchus mykiss) exposed to estrogenic alkylphenolic chemicals. Environ. Toxicol. Chem. 15,194-202.

[10] Kolpin, D.W., Furlong, E.T., Meyer, M.T., Thurman, E.M., Zaugg, S.D., Barber, L.B., Buxton, H.T., 2002. Pharmaceuticals, hormones, and other wastewater contaminants in U.S. streams, 19992000: a national reconnaissance. Environ Sci Technol 36, 1202-1211.

[11] Kotai, J., 1972. Introductions for Preparation of Modified Nutrient Solution Z8 for Algae. Norwegian Intsitute for Water research, Oslo, B-11/ 69, 1-5

[12] Naz, R.K., 2005. Endocrine disruptors: effects on male and female reproductive systems Boca Raton, FL: CRC Press.

[13] Vo, T.M.C., Nguyen, T.S., Bui, B.T., Bui, L.T.K., Do-Hong, L.C., Nguyen, P.D., Nguyen, T.P., Dao, T.S., 2014. Chronic effects of the atrazine and estriol on Daphnia magna. Vietnam J. Sci. \& Tech. 52 (3A), 323-329.

[14] Weyer, P., Riley, D., 2001. Endocrine disruptors and pharmaceuticals in drinking water. Denver, CO: AWWA Research Foundation and American Water Works Association.

[15] Zhang, L., Gibble, R., Baer, K.N., 2003. The effects of 4-nonylphenol and ethanol on acute toxicity, embryo development, and reproduction in Daphnia magna. Ecotoxicol. Environ. Saf. 55, 330-337. 